\title{
ANALYSIS OF AIR TEMPERATURE TRENDS: CITY OF PODGORICA (MONTENEGRO)
}

\author{
NIKOLA BAČEVIĆ1 ${ }^{*}$, ALEKSANDAR VALJAREVIĆ ${ }^{1}$ ，DUŠAN KIĆOVIĆ ${ }^{2}$ NIKOLA \\ MILENTIJEVIĆ ${ }^{1}$, MARKO IVANOVIĆ ${ }^{1}$, MELIHA MUJEVIĆ ${ }^{1}$
}

${ }^{1}$ Faculty of Natural Sciences and Mathematics, University of Priština, Kosovska Mitrovica, Serbia

${ }^{2}$ The College of Tourism, Academy of Applied Studies, Belgrade, Serbia

\begin{abstract}
This paper presents the results of the analyzed trends for three categories of parameters: average annual air temperature (YT), average maximum air temperature (YTx) and average minimum air tempe rature (YTn) for the Podgorica Meteorological Station in the Republic of Montenegro. The aim of this paper is to present possible climate changes based on the results obtained from the analyzed air temperature trends. The methodology is based on the application of: a) linear trend equations, b) trend magnitudes and c) Mann-Kendall trend test. The data from the respectable meteorological station in Podgorica for the period from 1947 to 2018 were used in order to estimate the trend. The obtained results indicate a statistically significant positive trend for all analyzed time series. Analyzing the trend test hypotheses, it was concluded that in all three cases the Ha hypothesis prevails. Average annual air temperature in Podgorica increased by $1.4^{\circ} \mathrm{C}$, average maximum air temperature increased by $2.5^{\circ} \mathrm{C}$ and average minimum air temperature increased by $0.6^{\circ} \mathrm{C}$. In accordance with the trends analyzed, the increase in air temperature is dominant in the capital of the Republic of Montenegro.
\end{abstract}

Keywords: Climate changes, Air temperature, Mann-Kendall test, Podgorica, Montenegro.

\section{INTRODUCTION}

The trend of increasing average annual air temperature has been identified worldwide. However, the spatio-temporal distribution of the increase in global air temperature is not uniform on Earth. The rise in air temperature varies by region. A higher rise in air temperature was observed in the northern hemisphere. Regional differences in terms of increasing average global air temperature are in the range of $0.65^{\circ} \mathrm{C} 1.06^{\circ} \mathrm{C}$. This is indicated by various reports given by the International Panel on Climate Change (IPCC, 2007; IPCC, 2014; IPCC, 2018). Also, in Europe there is a statistical trend of increasing average annual air temperature. The data obtained from various meteorological stations across Europe, (Klein et al., 2002) indicated an upward trend. The same rising trend in Europe has been observed with average seasonal air temperatures (Brázdil et al., 1996; Brunetti et al., 2004; Feidas et al., 2004; Brunet et al., 2007). Therefore, trends in the increase of air temperatures in the greatest part of Europe were recorded during the $20^{\text {th }}$ century. They were most pronounced during the 1990s (Kovats et al., 2014). A similar trend continued in the next century, so the four warmest years since instrumental measurements were recorded in the second decade of the $21^{\text {st }}$ century - 2015, 2016, 2017 and 2018 (WMO, 2019). Previous research into climate change in the wider region and in Southeast Europe has addressed similar issues (Jovanović et al., 2002; Unkašević \& Tošić, 2013; Tosić et al., 2016; Trbić et al., 2017; Gavrilov et al., 2015; Gavrilov et al., 2016; Gavrilov et al., 2018; Ivanović et al., 2016; Popov et al., 2017; Popov et

* Corresponding author: nikola.bacevic@ pr.ac.rs GEOGRAPHY, GEOSCIENCE AND ASTRONOMY al., 2018; Vukoičić et al., 2018; Papić et al., 2019) and aridity as an indicator of climate change (Hrnjak et al., 2014; Bačević et al., 2017; Radaković et al., 2017; Milentijević et al., 2018). A statistically significant upward trend in the average annual air temperature was also observed in the urban area (Savić et al, 2013; Bačević et al., 2018). This paper analyzes recent trends for average, average maximum and average minimum air temperatures in the urban area of Podgorica. The problem of climate in the study area was addressed by numerous authors (Vujević, 1953; Radinović, 1981; Burić et al., 2007; Burić et al., 2011; Burić et al., 2013; Burić et al., 2014; Burić et al., 2015; Burić et al., 2018; Burić et al., 2019).

\section{MATERIAL AND METHODS}

Study area

In geomorphotectonic sense, the area of Podgorica is part of the mid-Montenegrin valley. The valley is an area that extends from the Gatačko Field in Herzegovina to Lake Skadar, while the river Bojana opens to the Adriatic Sea. The valley consists of: Golija and Duga (800 to $1000 \mathrm{~m}$ of a.h.), Niksic Field (600 to 660 meters), Bjelopavlić plain (40 to 56 meters) and PodgoricaSkadar Valley (6 to 67 meters). North of Skadar Lake (as part of the Podgorica-Skadar basin) is the Zeta plain. It covers the lower course of the Morača River. This is the largest continental lowland of Montenegro, measuring about $240 \mathrm{~km}^{2}$. The plain is low in altitude (except for limestone mounds) and is slightly sloping from northeast to southwest and south. In its northern part is Podgorica. The administrative center and capital of Podgorica is located in the central part of the Republic of 
Montenegro. The urban area covers an area of about $1500 \mathrm{~km}^{2}$, which represents $10.5 \%$ of the total territory. In the north and northwest, the municipalities of Podgorica are bordered by the municipalities of Kolašin, Andrijevica and Danilovgrad, and in the south and southwest by the municipalities of Bar, Ulcinj and Cetinje. To the east, the municipality borders with the Republic of Albania. Podgorica Weather Station is located in Golubovci, $10 \mathrm{~km}$ from the city center (Burić et al., 2007). According to Kepen's climate classification, Podgorica and its surroundings belong to the Csa subtype. It is characterized by warm and dry summers and moderate and rainy winters. The average temperature of the coldest month is between $-3^{\circ} \mathrm{C}$ and $18^{\circ} \mathrm{C}$ Summer is the warmest period of the year, with the warmest monthly temperature $>22^{\circ} \mathrm{C}$ (Burić et al., 2014).

Data

This paper uses data for average annual, average maximum and average minimum air temperatures, published in the Meteorological Yearbooks of the Republic Hydrometeorological Institute of the Republic of Montenegro from the meteorological station in Podgorica, for the period from 1947 to 2018 (http://www.meteo.co.me/). Coordinates of defined study area are: $\varphi=42^{\circ} 26^{\prime} 00^{\prime \prime} \mathrm{N}, \lambda=19^{\circ} 17^{\prime} 00^{\prime \prime} \mathrm{E}$ and $49 \mathrm{~m}$ of altitude. The geographical location of the Podgorica meteorological station is shown in Map 1. The technical and critical control of these measurements was realized by the Republic Hydrometeorological Institute of the Republic of Montenegro.
Long time climate series used for analyses are influenced by inhomogenieties. They are caused by few factors: a) relocation of the meteorological station, b) the replacement of instruments or/and observers, c) changes in observation rules, d) changes in the environment of the meteorological station, etc. planting or/and uprooting of trees and grass, e) human errors in data processing. Many authors presented different homogeneity test: a) standard normal homogeneity test (SNHT; Alexandersson, 1986; Alexandersson \& Moberg, 1997); b) Pettitt's test (Pettitt, 1979); c) Von Neumann ratio test (Von Neumann, 1941). If these inhomogenieties are not detected and treated adequately, results of climate analyses will be inaccurate. In paper Savić et al. (2012) homogenisation test provided relatively low break point magnitudes and adjustment values (from \pm 0.03 to $\pm 0.26^{\circ} \mathrm{C}$ ), probably caused by small territory of Vojvodina Province, not too large distance among weather stations and the geographical area with a gentle relief, so generally, the climate is free from orographic effects. Furthermore, these stations are a group of higher-rank stations (main stations) which probably resulted in higher quality of observations. Homogenisation process show relatively low differences of mean monthly (from $0^{\circ} \mathrm{C}$ to $0.12^{\circ} \mathrm{C}$ ) and trend (from $0{ }^{\circ} \mathrm{C}$ to $0.001^{\circ} \mathrm{C} /$ per year) air temperature values between raw and homogenised time series. Similarly, here are dominantly factors as small territory of Podgorica Municipality, plain relief, one main station in study area. For this reasons, in this paper weren't applied none of mentioned homogeneity tests.

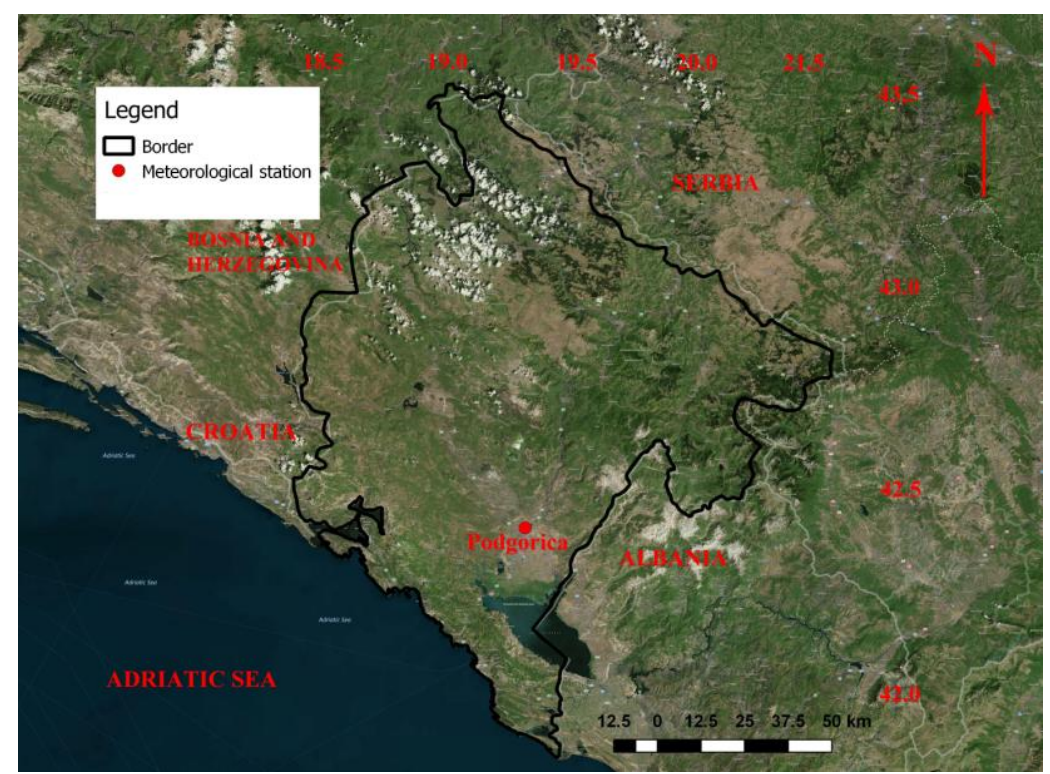

Figure 1. Physical-geographical map of the Republic of Montenegro and the geographical location of the capital Podgorica, marked in red.

\section{Method}

The paper uses three statistical approaches in order to analyze air temperature trends. The trend equation is the first statistical approach, which is of utmost importance for the analysis, evaluation and distribution of short-term climate change. Another statistical approach consists in determining the magnitude of the trend (Mann, 1945; Kendall, 1938). Whereas, the third statistical approach is to test the MK trend test, for each time series separately (Gavrilov et al., 2016). Air temperature trends were determined using EXCEL, which is part of the MICROSOFT OFFICE XLSTAT software package, used to 
calculate value levels, $p$, and to test hypotheses (https://www.xlstat.com/en).

The trend equation

The linear trend is a statistical procedure, which is of great importance in the analysis and evaluation of changes in air temperatures (Hrnjak et al., 2014). The equation takes the following form:

$$
y=a x+b
$$

where $y$ represents the air temperatures in ${ }^{\circ} \mathrm{C}$ and $a$ is the magnitude of the slope, $x$ is the time series, while $b$ is the temperature at the beginning of the period. The value of the trend of air temperature is in function of the slope size. There are three possible scenarios: a) the slope size is greater than zero - the trend is positive; b) equal to zero - no trend; v) less than zero the trend is negative.

\section{Trend Magnitude}

Trend magnitude is determined according to the trend equation (Gavrilov et al, 2015), i.e.:

$$
\Delta y=y(1948)-y(2018)
$$

where $\Delta y$ represents the trend magnitude expressed in ${ }^{\circ} \mathrm{C}, y$ (1948) in the equation is the value of the variable at the beginning of the period and $y$ (2018) represents its value at the end of the period. When it comes to trend magnitude, there are three possible scenarios here: a) when it is greater than zero - the trend is negative; b) when $\Delta y$ is less than zero - the trend is positive; c) when equal to zero - there is no trend.

\section{RESULTS AND DISCUSSION}

\section{Trend parameters}

The results are presented as average annual air temperatures (P-YT), as average annual maximum air temperatures (P-YTx) and as average annual minimum air temperatures (P-YTn). The MK trend test analysis is presented for a total of three time series for the Podgorica meteorological station. Figure 2 show the average annual, average maximum and average minimum air temperatures, trend test equations and linear trend for the Podgorica Meteorological Station for the observed period from 1947 to 2018 . Trend magnitudes, $\Delta y\left({ }^{\circ} \mathrm{C}\right)$ and trend probability $p$, for each of the three time series are presented in Tables 1 and 2.

Table 1. The trend equation $\mathrm{y}$, the trend magnitude $\Delta y$, and probability $p$ of the confidences for 3 time series.

\begin{tabular}{|c|c|c|c|}
\hline Time series & Trend equation & $\Delta y\left({ }^{\circ} \mathrm{C}\right)$ & $p(\%)$ \\
\hline$P-Y T$ & $y=0.0196 x+15.044$ & 1.4 & $<0.0001$ \\
\hline$P-Y T x$ & $y=0.035 x+25.757$ & 2.5 & $<0.0001$ \\
\hline$P-Y T n$ & $y=0.0087 x+5.0861$ & 0.6 & 0.0176 \\
\hline
\end{tabular}

Table 2. The main results of the analysis of temperature trends for 3 time series.

\begin{tabular}{|c|c|c|}
\hline Time series & Trend equation & Classical MK test \\
\hline$P-Y T$ & positive trend & positive significant trend \\
\hline$P-Y T x$ & positive trend & positive significant trend \\
\hline$P-Y T n$ & positive trend & positive significant trend \\
\hline
\end{tabular}

\section{Trend evaluation}

The obtained MK trend test results for average air temperatures in Podgorica are shown in Table 2 for the observed period from 1947 to 2018. Of the three time series, in all cases the MK trend test analyzes showed a statistically significant positive trend. Also, a positive statistical trend is shown by all numerical parameters and graphical representations (Figure 2).

For the P-YT and P-YTx time series for Podgorica Meteorological Station, the $p$ value is $<0.0001$. For both time series above, the same values of the Mk trend test analysis apply. As the computed $p$-value is lower than the significance level alpha $=0.05$, they should reject the null hypothesis $\mathrm{H} 0$, and accept the alternative hypothesis Ha. The risk to reject the null hypothesis is Ha, while it is true is lower than $0.01 \%$.

For the P-YTn time series for the Podgorica Meteorological Station, the $p$ value is 0.0176 . As the computed $\mathrm{p}$-value is lower than the significance level alpha $=0.05$, one should reject the null hypothesis $\mathrm{H} 0$, and accept the alternative hypothesis Ha. The risk to reject the null hypothesis Ha while it is true is lower than $1.77 \%$.

Individually observed in Podgorica, the highest temperature increase of $2.5^{\circ} \mathrm{C}$ was noticed in the P-YTx time series. This is followed by an average air temperature increase of $1.4^{\circ} \mathrm{C}$ for the $\mathrm{P}-\mathrm{YT}$ time series. Whereas, the least average temperature increase of $0.6^{\circ} \mathrm{C}$ was observed for the P-YTn time series. In all three cases, a statistically positive trend was observed, where the Ha hypothesis prevails. According to the IPCC (2018) report on a global average annual average, the average maximum and minimum air temperatures of $0.6^{\circ} \mathrm{C}$ to $1.8^{\circ} \mathrm{C}$ are significantly more pronounced in the Montenegrin capital. Similar results were observed in Bosnia and Herzegovina (Mostar and Bileća). In Mostar, the average annual temperature rose by $0.9{ }^{\circ} \mathrm{C}$ and in Bileća by $1.7^{\circ} \mathrm{C}$. Average maximum temperatures in Mostar and Bileća increased by $1.9^{\circ} \mathrm{C}$ and $1.3^{\circ} \mathrm{C}$, respectively, and average minimum temperatures increased by $1.4^{\circ} \mathrm{C}$ and $0.7^{\circ} \mathrm{C}$ (Papić et al., 2019). Also, a positive trend of increasing air temperature is noticed in Vojvodina (Gavrilov et al., 2015), Novi Sad as an urban environment (Savić et al., 2013), and Kosovo and Metohija region (Gavrilov et al., 2018). The average air temperature increased by $1.2^{\circ} \mathrm{C}$. Such results confirm that there are tendencies that suggest an increase in average air temperature on regional and national levels. 


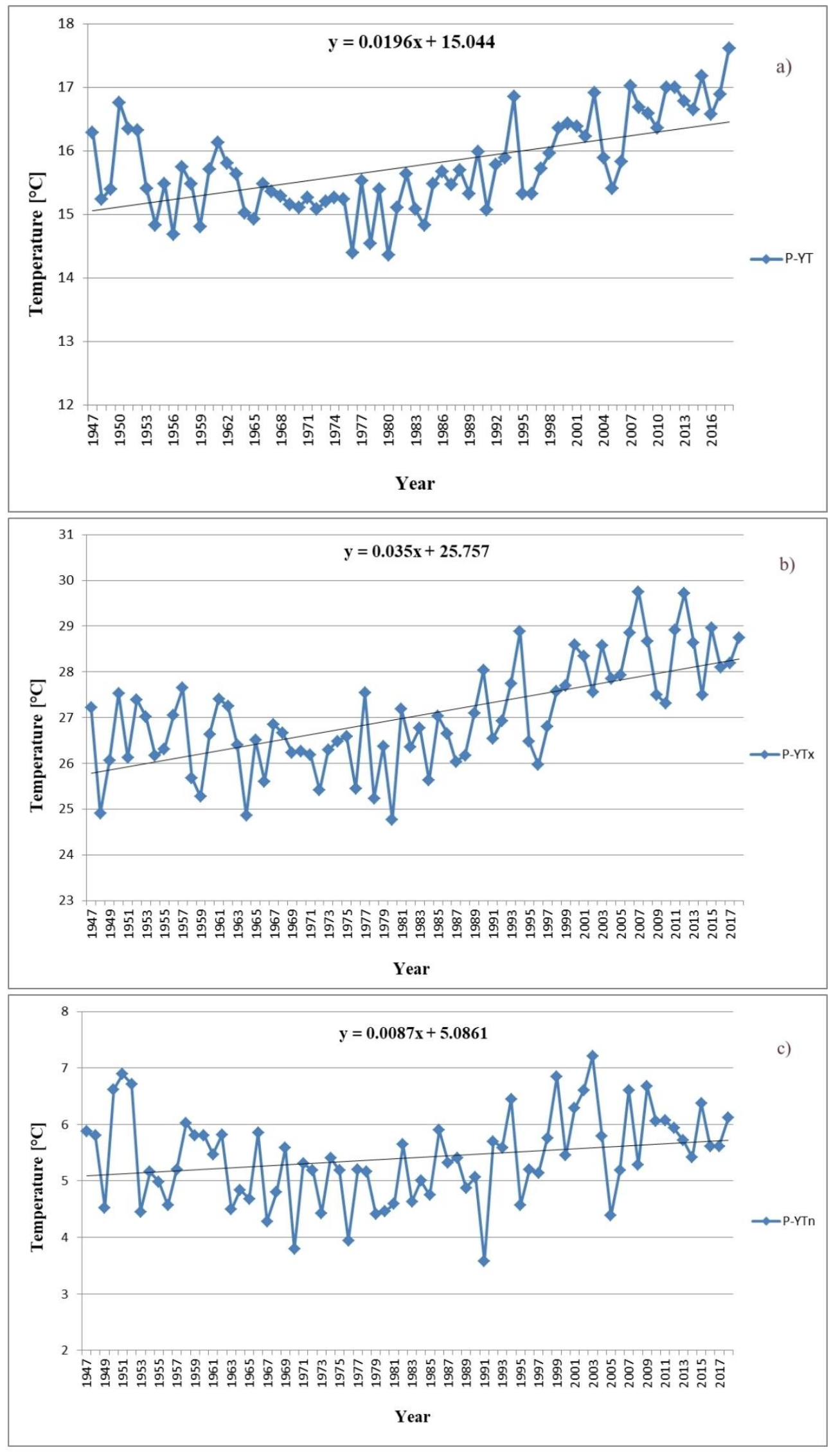

Figure 2. Graphical representation of a) average annual, b) average maximum, c) average minimum air temperature, trend equation and linear trend for the observed period from 1947 to 2018 in Podgorica. 


\section{CONCLUSION}

Analyzing the trend equation, trend magnitude and $\mathrm{MK}$ trend test for average annual, average annual maximum and average annual minimum air temperature in Podgorica, a significant increase in air temperature was observed in all time series. Hypothesis $\mathrm{Ha}$ is prevalent, with a very low risk of rejecting the hypothesis. Positive trends for the Podgorica Meteorological Station represent a manifested pattern of climate change globally in line with the conclusions of the International Panel on Climate Change (IPCC, 2018). Unfortunately, this global problem has not, in scientific terms, been given much attention in the Republic of Montenegro. Future research should be focused on monitoring and analyzing climate extremes in the future. Also, it should be borne in mind that the analysis of trends was carried out on the basis of the parameters from the only station in the city territory. The presented results, due to the large heterogeneity of the space, show the general state of the selected parameters. There are many factors that influence the existence of microclimate differences in the area: degree of urbanization, terrain hypsometry, hydrographic objects, vegetation. For these reasons, monitoring of the required parameters through automatic weather stations would be necessary. This is possible if an AMS network is organized in the city. Climate change leads to numerous socio-economic consequences such as extreme climate events (aridity, drought an unfavorable circumstance in agriculture), consequences for human health, reduction or even the disappearance of terrestrial and marine ecosystems.

\section{REFERENCES}

Alexandersson, H. 1986. A homogeneity test applied to precipitation data. Journal of Climatology. 6, pp. 661-675.

Alexandersson, H., \& Moberg, A. 1997. Homogenization of Swedish temperature data. Part I: homogeneity test for linear trends. International Journal of Climatology. 17, pp. 25-34.

Bačević, R. N, Vukoičić, Z. D., Nikolić, M., Janc, N., Milentijević, N., \& Gavrilov B. M. 2017. Aridity in Kosovo and Metohija, Serbia. Carpathian Journal of Earth and Environmental Sciences. 12(2), pp. 563-570.

Bačević, R. N., Pavlović, M., \& Rašljanin, I. 2018. Trend Assessing Using Mann-Kendall's Test for Priština Meteorological Station Temperature and Precipitation Data, Kosovo and Metohija, Serbia. The University Thought Publication in Natural Sciences, (8)2, pp. 39-43. doi:10.5937/univtho8-19513

Burić, D., Ivanović, R. \& Mitrović, L. 2007. Klima Podgorice. Hidrometeorološki zavod Crne Gore, Podgorica.

Burić, D., Ducić, V. \& Luković, J. 2011. Kolebanje klime u Crnoj Gori u drugoj polovini XX i početkom XXI vijeka. Posebna izdanja Crnogorske akademije nauka i umjetnosti, knjiga 36, pp. 6-261. Podgorica, IVPE Cetinje.

Burić, D., Ducić, V., \& Mihajlović, J. 2013. The climate of Montenegro: Modificators and types - part one. Glasnik
Srpskog Geografskog Društva, 93(4), pp. 83-102. doi.org/10.2298/GSGD1304083B

Burić, D., Ducić, V., \& Mihajlović, J. 2014. The climate of Montenegro: Modificators and types - part two. Glasnik Srpskog Geografskog Društva. 94(1), pp. 73-90. doi:10.2298/GSGD1401073B

Burić, D., Ducić, V., Mihajlović, J., Luković, J., \& Dragojlović, J. 2015. Recent extreme air temperature changes in Montenegro. Glasnik Srpskog Geografskog Društva, 95(4), pp. 53-46. doi.org/10.2298/GSGD140626002B

Burić, B. D., Dragojlović, M. J., Milenković, M., Popović, Z. Lj. \& Doderović, M. M. 2018. Influence of variability of the East Atlantic Oscillation on the air temperature in Montenegro. Thermal Science, 22(1), pp. 759-766. doi.org/10.2298/TSCI170710211B

Burić, D., Milenković, M., \& Ducić, V. 2019. The specificities of the climate of Danilovgrad (Montenegro). Glasnik Srpskog Geografskog Društva, 99(1), pp. 19-28. doi.org/10.2298/GSGD1901019B

Brázdil, R., Budíková, M., Auer, I., Böhm, R., Cegnar, T., Faško, P., Lapin, M., Gajić-Čapka, M., Zaninović, K., Koleva, E., Niedźwiedź, T., Ustrnul, Z., Szalai, S. \& Weber, R. O. 1996. Trends of maximum and minimum daily temperatures in central and southeastern Europe. International Journal of Climatology, 16(7), Manhattan. doi: 10.1002/(SICI)10970088(199607)

Brunet, M., Jones, P. D., Sigro, J., Saladie, O., Aguilar, E., Moberg, A., Della-Marta, P. M., Lister, D., Walther, A. \& López, D. 2007: Temporal and spatial temperature variability and change over Spain during 1850-2005. Journal of Geophysical Research: Atmospheres 112. Manhattan. doi: 10.1029/2006JD008249

Brunetti, M., Buffoni L., Mangianti, F., Maugeri, M. \& Nanni, T. 2004. Temperature, precipitation and extreme events during the last century in Italy. Global and Planetary Change, 40(1/2). New York, Amsterdam, London. doi: 10.1016/S0921-8181(03)00104-8

Feidas, H., Makrogiannis, T., \& Bora-Senta, E. 2004. Trend analysis of air temperature time series in Greece and their relationship with circulation using surface and satellite data: 1955-2001. Theoretical and Applied Climatology, 79(3-4), pp. 185-208. doi:10.1007/s00704-0040064-5

Gavrilov, M. B., Marković, S. B., Jarad, A. \& Korać, V. M. 2015. The analysis of temperature trends in Vojvodina (Serbia) from 1949 to 2006. Thermal Science, 19(2), pp. 339350. doi.org/10.2298/TSCI150207062G

Gavrilov, M. B., Tošić, I., Marković, S. B., Unkašević, M. \& Petrović, P. 2016. The analysis of annual and seasonal temperature trends using the Mann-Kendall test in Vojvodina, Serbia. IDÖJÁRÁS, 122(2), pp. 203-216. doi:10.28974/idojaras.2018.2.6

Gavrilov, M. B., Marković, S. B., Janc, N., Nikolić, M., Valjarević, A., Komac, B., Zorn, M., Punišić, M. \& Bačević, N. 2018. Assessing average annual air temperature trends using the Mann-Kendall test in Kosovo. Acta geographica Slovenica, 58(1), 8-25. doi:10.3986/ags.1309

Hrnjak, I., Lukić, T., Gavrilov, M. B., Marković, S. B., Unkašević, M. \& Tošić, I. 2014. Aridity in Vojvodina, 
Serbia. Theoretical and Applied Climatology, 115, pp. $323-$ 332. doi 10.1007/s00704-013-0893-1

IPCC. 2007. Intergovernmental Panel Climate Change. The physical science basis. In: Solomon, S., Qin. D., Manning, M., Chen, Z., Marquis, M., Averyt, K. B., Tignor, M., Miller, H. L. (eds.). Contribution of Working Group I to the Fourth Assessment Report of the Intergovernmental Panel on Climate Change. Cambridge University Press, Cambridge

IPCC. 2014. Climate Change 2014: Synthesis Report. Contribution of Working Groups I, II and III to the Fifth Assessment Report of the Intergovernmental Panel on Climate Change [Core Writing Team, R.K. Pachauri and L.A. Meyer (eds.)]. IPCC, Geneva, Switzerland, pp. 151.

IPCC. 2018. Summary for Policymakers. In: Global warming of $1.5^{\circ} \mathrm{C}$. An IPCC Special Report on the impacts of global warming of $1.5^{\circ} \mathrm{C}$ above pre-industrial levels and related global greenhouse gas emission pathways, in the context of strengthening the global response to the threat of climate change, sustainable development, and efforts to eradicate poverty [V. Masson-Delmotte, P. Zhai, H. O. Pörtner, D. Roberts, J. Skea, P. R. Shukla, A. Pirani, W. MoufoumaOkia, C. Péan, R. Pidcock, S. Connors, J. B. R. Matthews, Y. Chen, X. Zhou, M. I. Gomis, E. Lonnoy, T. Maycock, M. Tignor, T. Waterfield (eds.)]. World Meteorological Organization, Geneva, Switzerland, 32.

Ivanovic, R., Valjarevic, A., Vukoicic, D., \& Radovanovic, D. 2016. Climatic regions of Kosovo and Metohija. The University Thought - Publication in Natural Sciences, 6(1), pp. 49-54. doi:10.5937/univtho6-10409

Jovanović, G., Reljin, I. \& Savić, T. 2002. NAO Influence on climate variability in FRY. 18th International conference on Carpathian meteorology, Belgrade.

Kendall, M. 1938. A new measure of rank correlation. Biometrika, 30, pp. 81-89.

Klein, T. A. M. G., Wijngaard, J. B., Können, G. P., Böhm, R., Demarée, G., Gocheva, A., \& et al., 2002. Daily dataset of 20th-century surface air temperature and precipitation series for the European Climate Assessment. International Journal of Climatology, 22(12), pp. 1441-1453. doi:10.1002/joc.773

Kovats, R. S., Valentini, R., Bouwer, L. M., Georgopoulou, E., Jacob, D., Martin, E., Rounsevell, M. \& Soussana, J. F. 2014. Europe. In: Barros, V. R., Field, C. B., Dokken, D. J., Mastrandrea, M. D., Mach, K. J., Bilir, T. E., Chatterjee, M., Ebi, K. L., Estrada, Y. O., Genova, R. C., Girma, B., Kissel, E. S., Levy, A.N., MacCracken, S., Mastrandrea, P. R., White, L.L.[eds.].Climate Change 2014: Impacts, Adaptation, and Vulnerability. Part B: Regional Aspects. Contribution of Working Group II to the Fifth Assessment Report of the Intergovernmental Panel on Climate Change. Cambridge University Press, Cambridge, United Kingdom and New York, NY, USA.

Mann, H. B. 1945. Non-parametric Tests Against Trend. Econometrica, 13, pp. 245-259.

Milentijević, N., Dragojlović, J., Ristić, D., Cimbaljević, M., Demirović, D. \&, Valjarević, A. 2018. The assessment of aridity in Leskovac Basin, Serbia (1981-2010). Journal of the Geographical Institute "Jovan Cvijić", 68(2), pp. 249-264. doi.org/10.2298/IJGI1802249M
Papić, D., Bačević, R. N., Valjarević, A., Milentijević, N., Gavrilov, B. M., Živković, M. \& Marković, B. S. 2019. Assessment of Air Temperature Trends in South and Southeast Bosnia and Herzegovina (B\&H) from 1961 to 2017. IDÖJÁRÁS (ACCEPTED FOR PUBLICATION).

Pettitt, A.N. 1979. A non- parametric approach to the change- point problem. Journal of Applied Statistics. 28, pp. 126-135.

Popov, T., Gnjato, S. \& Trbić, G. 2017. Trends in extreme temperatures indices in Bosnia and Herzegovina: A case study of Mostar. Herald, 21, pp. 107-132. doi: 10.7251/HER2117107P

Popov, T., Gnjato, S., Trbić, G. \& Ivanišević, M. 2018. Recent Trends in Extreme Temperature Indices in Bosnia and Herzegovina. Carpathian Journal of Earth and Environmental Sciences, 13, pp. 211-224.

Radaković, G. M., Tošić, A. I., Bačević, R. N., Mađan, D., Marković, S. B. \& Gavrilov, M. B. 2017. The analysis of aridity in Central Serbia from 1949-2015. Theoretical and Applied Climatology, 133(3-4) pp. 887-898. doi:10.1007/s00704-017-2220-8

Radinović, Đ. 1981. Vreme i klima Jugoslavije. Beograd: IRO "Građevinska knjiga".

Republic Hydrometeorological Service of Republika Montenegro, http://www.meteo.co.me/ (accessed 09.02.2019)

Savić, S., Milošević, D., Marković, V. \& Kujundžić Dačović, R. 2012. Homogenisation of mean air temperature time series from Vojvodina (North Serbia). Geographica Pannonica. 16(2), pp. 38-43.

Savić, S., János, U., Tamás, G., Milošević, D. \& Popov, Z. 2013. Urban heat island research of Novi Sad (Serbia): A review. Geographica Pannonica, 17(1), pp. 32-36.

Tošić, I., Zorn, M., Ortar, J., Unkašević, M., Gavrilov, M. B. \& Marković, S. B. 2016. Annual and seasonal variability of precipitation and temperatures in Slovenia from 1961 to 2011. Atmospheric Research, 168, pp. 220-233. doi.org/10.1016/j.atmosres.2015.09.014

Trbić, G., Popov, T. \& Gnjato, S. 2017. Analysis of air temperature trends in Bosnia and Herzegovina. Geographica Pannonica, 21, pp. 68-84. doi.org/10.5937/GeoPan1702068T

Unkašević, M. \& Tošić, I. 2013. Trends in temperature indices over Serbia: relationships to large-scale circulation patterns. International Journal of Climatology, 33(15), pp. 3152-3161. doi:10.1002/joc.3652

Von Neumann J. 1941. Distribution of the ratio of the mean square successive difference to the variance. Annals of Mathematical Statistics. 12, pp. 367-395.

Vujević, P. 1953. Podneblje FNR Jugoslavije. Arhiv za poljoprivredne nauke, 6, pp. 3-42.

Vukoičić, Z. D., Milosavljević, A. S., Penjišević, T. I., Bačević, R. N., Nikolić, M., Ivanović, D. R., Jandziković, M. B. 2018. Spatial analysis of temperature and its impact on the sustainable development of mountain in Central and Western Serbia. Időjárás-Quarterly Journal of the Hungarian Meteorological Service. 122(3), 259-283.

WMO. 2019. Statement on the State of the Global Climate in 2018. WMO-No. 1233. World Meteorological Organization, Geneva, Switzerland.

XLSTAT, http://www.xlstat.com/en/ (accessed 10.03.2019) 